\title{
Art, Design and Visual Culture An Introduction
}


Also by the same author:

Fashion as Communication 


\title{
Art, Design and Visual Culture
}

\author{
An Introduction
}

MALCOLM BARNARD

palgrave 


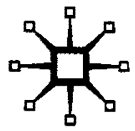

C Malcolm Bamard 1998

Softcover reprint of the hardcover 1st edition 1998

All rights reserved. No reproduction, copy or transmission of this publication may be made without written permission.

No paragraph of this publication may be reproduced, copied or transmitted save with written permission or in accordance with the provisions of the Copyright, Designs and Patents Act 1988, or under the terms of any licence permitting limited copying issued by the Copyright Licensing Agency, 90 Tottenham Court Road, London W1T 4LP.

Any person who does any unauthorised act in relation to this publication may be liable to criminal prosecution and civil claims for damages.

The author has asserted his right to be identified as the author of this work in accordance with the Copyright, Designs and Patents Act 1988.

Published by

PALGRAVE MACMILLAN

Houndmills, Basingstoke, Hampshire RG21 6XS and 175 Fifth Avenue, New York, N. Y. 10010 Companies and representatives throughout the world

PALGRAVE MACMILLAN is the global academic imprint of the Palgrave Macmillan division of St. Martin's Press, LLC and of Palgrave Macmillan Ltd. Macmillan is a registered trademark in the United States, United Kingdom and other countries. Palgrave is a registered trademark in the European Union and other countries.

\section{ISBN 978-0-333-67526-7} DOI 10.1007/978-1-349-26917-4

This book is printed on paper suitable for recycling and made from fully managed and sustained forest sources.

A catalogue record for this book is available from the British Library.

A catalog record for this book is available from the Library of Congress. 
To my parents 


\section{Contents}

List of Illustrations $\quad \mathbf{x}$

Acknowledgements $\quad$ xi

$\begin{array}{ll}\text { Introduction } & 1\end{array}$

1 What is Visual Culture? 10

Introduction 10

The visual $\quad 11$

Everything that can be seen 11

Everything produced or created by humans that can be seen $\quad 12$

Functional or communicative intent: design $\quad 15$

Aesthetic intent: art 16

The cultural $\quad 18$

Unilinear elite culture $\quad 19$

Dominant masculine mass culture $\quad 23$

Multilinear popular (sub)culture $\quad 26$

$\begin{array}{ll}\text { Conclusion } & 30\end{array}$

2 How May It Be Studied? $\quad 32$

Introduction $\quad 32$

Approaches, methods, topics and themes 33

Disciplines and subjects $\quad 50$

Conclusion $\quad 56$

3 Producers: Artists and Designers 58

Introduction $\quad 58$

Portraits of the artist and the designer 59

$\begin{array}{ll}\text { Craft guilds } & 61\end{array}$

Academies $\quad 63$

Professional societies, cooperatives and unions 
Art and design movements $\quad 68$

Memphis $\quad 69$

Der Ring 'neue Werbegestalter' 71

The Situationist International $\quad 73$

Der Blaue Reiter $\quad 74$

The Pre-Raphaelite Brotherhood $\quad 75$

$\begin{array}{ll}\text { Conclusion } & 76\end{array}$

4 Consumers: Markets, Publics and Audiences 79

$\begin{array}{ll}\text { Introduction } & 79\end{array}$

$\begin{array}{lr}\text { Patronage } & 80\end{array}$

$\begin{array}{ll}\text { Church } & 82\end{array}$

$\begin{array}{lr}\text { Court } & 83\end{array}$

Private $\quad 85$

$\begin{array}{lr}\text { Public } & 87\end{array}$

State $\quad 89$

The market $\quad 93$

Sponsorship $\quad 98$

$\begin{array}{lr}\text { Conclusion } & 100\end{array}$

5 Media, Access and Ownership 102.

$\begin{array}{ll}\text { Introduction } & 102\end{array}$

Human resources 104

Material resources $\quad-106$

Hand-made $\quad 108$

$\begin{array}{lr}\text { Tool-made } & 109\end{array}$

Machine-made 110

Computer-generated 119

$\begin{array}{ll}\text { Conclusion } & 121\end{array}$

6 Signs, Codes and Visual Culture 124

Introduction 124

Art and design as conscious performance 125

Art and design as high quality 128

Art, design and aesthetic intention 129

Art and design as sign systems 131

External sign systems 133

Internal sign systems $\quad 137$

Crossover 140

$\begin{array}{ll}\text { Conclusion } & 141\end{array}$ 
7 Different Types of Art and Design 143

Introduction $\quad 143$

Types of art and design $\quad 144$

Theatre designs $\quad 147$

Fashions: the suit $\quad 149$

Paintings: genres $\quad 152$

Cars: the Citroën ZX 158

Interior designs: the parlour 161

$\begin{array}{ll}\text { Conclusion } & 165\end{array}$

8 Visual Culture and the Social Process 166

Introduction 166

The social order $\quad 167$

$\begin{array}{ll}\text { Marxism } & 167\end{array}$

Max Weber $\quad 169$

Cultural producers 171

Challenging the social order $\quad 172$

Neutrality and the social order 180

Reproducing the social order 182

Consumption $\quad 185$

Passive consumption $\quad 186$

Active consumption: reproduction $\quad 188$

Active consumption: resistance 192

Conclusion 195

9 Conclusion 197

Bibliography 201

$\begin{array}{ll}\text { Index } & 208\end{array}$ 


\section{List of Illustrations}

1.1 Gilbert and George, In the Shit, 1996

1.2 Business suits, Brooks Brothers, $1996 \quad 29$

3.1 Sottsass, 'Carlton' room-divider 71

$\begin{array}{lll}3.2 & \text { Futura typeface } & 73\end{array}$

3.3 Holman Hunt, The Awakening Conscience, 1851-3 77

5.1 Tattoo, photography by Tim O'Sullivan, 1991

5.2 Hokusai (1760-1849), Cuckoo and Azalea, British Museum $\quad 105$

5.3 Bodoni typeface 111

6.1 Bon Marché store advertisement, New York, 1991

7.1 Fiat Bravo/Brava advertisement, $1997 \quad 145$

7.2 Zoot suit, Savoy Ballroom, New York, c.1938 151

7.3 Rembrandt, The Night Watch, 1642, Rijksmuseum, Amsterdam 156

7.4 Brueghel, Hunters in the Snow, 1565, Kunsthistoriches Museum, Vienna 157

7.5 Citroën advertising, $1991 \quad 159$

8.1 Thomas Gainsborough, Mr and Mrs Andrews, 1748, National Gallery, London 


\section{Acknowledgements}

Many of the ideas and approaches covered in this book were suggested to me during my time as a part-time lecturer in the History and Theory of Art and Design at Leeds Polytechnic (now Leeds Metropolitan University) between 1984 and 1990. My colleagues at that time included Jonathan Harris, Ian Heywood, Wendy Leeks, Richard Tyler and Anita Whittle. I am sure that they will recognise what I learned from them.

Many of these ideas and approaches have been refined and developed during my time at the University of Derby. My colleagues here have included Alan Barnes, Robert Burstow, Gail Day, Steve Edwards, David Heathcote, Stanley Mitchell, Giles Peaker, Josie Walter, Julia Welbourne and Rhiannon Williams. I am grateful to them all, and to my friend Chris Jenks, of Goldsmiths' College, University of London, for a great deal of help and many useful suggestions.

Catherine Gray, the commissioning editor, Houri Alavi, the assistant editor, and Nancy Williams have been of enormous help at Macmillan, as has the anonymous adviser whose maturity and rigour tightened up the work considerably. I am also grateful to Simon Birkett and Sally Edwards at the University of Derby for producing prints suitable for reproduction here from some often unpromising originals.

Finally, acknowledgements must be made to the Research Centre for Cultural History and Critical Theory, in the School of Art and Design at the University of Derby, which enabled me to take some time out from teaching in order to write. 
The author and publishers wish to thank the following for permission to use copyright material:

British Museum for Hokusai's Cuckoo and Azalea; DMB\&B and Fiat for the advertisement of Fiat Bravo/Brava; Gilbert and George for In the Shit; Interface RSCG and Citroën for the advertisements of the Citroën ZX; Kunsthistoriches Museum, Vienna, for Brueghel's Hunters in the Snow; National Gallery, London, for Gainsborough's $\mathrm{Mr}$ and Mrs Andrews; Rijksmuseum, Amsterdam, for Rembrandt's The Night Watch; Tim O'Sullivan for photograph of tattoos; UPI Newspictures for photograph of men wearing Zoot suits.

Every effort has been made to trace all the copyright-holders, but if any have been inadvertently overlooked the publishers will be pleased to make the necessary arrangement at the first opportunity. 